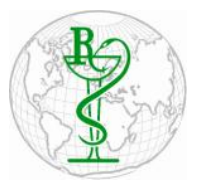

INDO GLOBAL JOURNAL OF

PHARMACEUTICAL SCIENCES

ISSN 2249- 1023

\title{
Determination of Amlodipine in Rat Plasma by UV Spectroscopy
}

\author{
P. Srinivasulu ${ }^{1 *}$, B.K. Gowthami ${ }^{2}$, T.N.V. Ganesh Kumar ${ }^{1}$, \\ D. Surya Narayana Raju ${ }^{1}$, S. Vidyadhara ${ }^{1}$ \\ ${ }^{1}$ Chebrolu Hanumaiah Institute of Pharmaceutical Sciences, Guntur, A.P. 522019, India \\ ${ }^{2}$ Adarsa College of Pharmacy, East Godhavari, A.P. 533285, India
}

\begin{abstract}
Address for Correspondance P Sirnivasulu, Vasuri38cology @gmail.com

ABSTRACT: Simple, precise and cost effective UV spectrophotometric method has been developed for the estimation of amlodipine in rat plasma. Amlodipine shows $\lambda \max$ at $343 \mathrm{~nm}$ in rat plasma. The drug follows Beer-Lambert law in the concentration range of $1-27 \mu \mathrm{g} / \mathrm{ml}$ with correlation coefficient of 0.999 in rat plasma. The methods were validated as per ICH guidelines. All validation parameters were within the acceptable range. The developed methods can be used to estimate the amount of amlodipine in a given formulation. (c) 2015 iGlobal Research and Publishing Foundation. All rights reserved.
\end{abstract}

Keywords Amlodipine; UV Spectrophotometer; Antihypertensive Drug.

\section{INTRODUCTION}

Amlodipine is chemically, (RS)-3-ethyl 5-methyl 2-[(2aminoethoxy) methyl]-4-(2-chlorophenyl)-6-methyl-1, 4dihydropyridine-3,5-dicarboxylate [1]. Amlodipine structure were shown in figure 1 . It is used as an anti hypertensive drug. Amlodipine is a dihydropyridine calcium antagonist (calcium ion antagonist or slowchannel blocker) that inhibits the movement of calcium ions into vascular smooth muscle cells and cardiac muscle cells $[2,3]$. Amlodipine has good oral bioavailability around $60 \%$. It is metabolized in the liver to inactive metabolites via CYP3A4. Amlodipine has half life of 3050 hours, and steady-state plasma concentrations are achieved after 7 to 8 days of daily dosing [4, 5]. According to the literature, it is found that amlodipine can be estimated by using UV-Vis spectrophotometry [6-8], HPLC [9-10]. The aim of the present work is to develop and validate an UV- spectrophotometric method for the estimation of amlodipine in rat plasma for different market formulations.

\section{MATERIALS \& METHODS}

\section{Chemicals and reagents}

Amlodipine was obtained as a gift sample from Medrich Pharmaceuticals Pvt. Ltd., Bangalore. A commercial tablet formulation was purchased from the local market. Ethanol and EDTA were purchased from Merck.

\section{Instrument}

A double beam UV-VIS spectrophotometer (Lab India) connected to computer loaded with UV Win software was used. The spectra were obtained with spectral bandwidth of $1 \mathrm{~nm}$ with wavelength accuracy of $\pm 0.5 \mathrm{~nm}$ with a pair of $10 \mathrm{~mm}$ matched quartz cells.

\section{Collection of plasma (Retro-orbital)}

The blood was collected from Albino rat (Retro-orbital) and poured into the centrifuge tubes containing EDTA. These centrifuge tubes were then placed into the 


\section{Indo Global Journal of Pharmaceutical Sciences, 2015; 5(3): 205-209}

centrifuge apparatus \& allowed to centrifuge for 20 minutes at $8000 \mathrm{rpm}$ and the plasma was separated and stored at $2-8^{\circ} \mathrm{C}$.

\section{Preparation of Diluent}

A mixture of rat plasma, ethanol and water in the ratio of 1:1:8werecentrifuged at $12000 \mathrm{rpm}$ for 15 minutes. The resulting supernatant was separated and stored at 2-8 $0 \mathrm{C}$. This stored solvent is used as the diluent for the study.

\section{Preparation and extraction of standard stock solution} $10 \mathrm{mg}$ of amlodipine was accurately weighed and transferred to a $100 \mathrm{~mL}$ volumetric flask containing plasma $(10 \mathrm{~mL})$ and water $(80 \mathrm{~mL})$ mixture as solvent. The solution was incubated for 6 hours at room temperature. After the incubation, $10 \mathrm{~mL}$ of ethanol was added and centrifuged at $12000 \mathrm{rpm}$ for 20 minutes. The supernatant was collected and used for the estimation of amlodipine using UV Spectrophotometer.

\section{Determination of wavelength of Amlodipine in rat plasma}

$1.0 \mathrm{ml}$ of standard stock solution was diluted to $10 \mathrm{ml}$ with the diluent to get the concentration of $10 \mu \mathrm{g} / \mathrm{ml}$ in a $10 \mathrm{~mL}$ volumetric flask. The UV spectrum of final solution obtained was scanned in the range of 200 to 400 $\mathrm{nm}$ against a mixture of plasma, ethanol and water in the ratio of 1:1:8 as a blank. The $\lambda \max$ was found to be 343 $\mathrm{nm}$. U V spectrum was shown in the figure 2 .

\section{Preparation of calibration curve for Amlodipine}

From the stock solution, $0.5,1,1.5,2,2.5,3,3.5$ and $4 \mathrm{~mL}$ solutions were taken out individually into a series of eight, $10 \mathrm{ml}$ volumetric flasks. The volume in each flask was made up to $10 \mathrm{ml}$ with diluent to yield final solution in the concentration range of 5.0 to $40 \mu \mathrm{g} / \mathrm{mL}$. The absorbance of all the concentrations were measured at $\lambda \max 343 \mathrm{~nm}$ against the blank. The results of calibration curve data for amlodipine are shown in Table1 and the calibration curve was shown in Figure 3.

\section{Estimation of Amlodipine in tablets}

Twenty tablets of amlodipine were weighed and finely powdered. A quantity of powder equivalent to $10 \mathrm{mg}$ of the drug was transferred to a $100 \mathrm{ml}$ volumetric flask containing plasma $(10 \mathrm{~mL})$ and water $(80 \mathrm{~mL})$ mixture as solvent. The solution was sonicated for 15 minutes and incubated for 6 hours at room temperature. After the incubation, $10 \mathrm{~mL}$ of ethanol was added and centrifuged at $12000 \mathrm{rpm}$ for 20 minutes. The supernatant was collected and used for the estimation of drug. The results are shown in Table 2.

\section{Method validation}

Linearity

A calibration curve was constructed at optimum experimental condition using absorbance values versus concentration in the range of $5.0-40 \mu \mathrm{g} / \mathrm{ml}$. It has shown linear relationship with the regression equation $\mathrm{y}=0.0331$ $\mathrm{x}$, where $\mathrm{y}$ is absorbance at $343 \mathrm{~nm}$ and $\mathrm{c}$ is the concentration of the sample in $\mu \mathrm{g} / \mathrm{ml}$. Correlation coefficient (0.999) indicates good linearity and adherence of the method to Beers law. The results are showed in Table 3.

\section{Accuracy}

This parameter was evaluated by the percent recovery studies at concentration levels of 80,100 and $120 \%$, which consisted of adding known amounts of amlodipine reference materials to a prequantified sample solution. Aliquots of sample solutions containing amlodipine at $10.0 \mu \mathrm{g} / \mathrm{mL}$ were transferred to three $10 \mathrm{~mL}$ volumetric flasks containing, respectively, $0.5,1.0$, and $1.5 \mathrm{~mL}$ amlodipine reference solution $(100 \mu \mathrm{g} / \mathrm{ml})$. The contents were mixed and diluted to volume in order to obtain final concentrations of 5,10 , and $15 \mu \mathrm{g} / \mathrm{mL}$ respectively. The recovery was verified by estimation of drugs in triplicate preparations at each specified concentration level. The spectrums were recorded in the UV range and then analyzed. The results are reported in terms of \% recovery in Table 3.

\section{Precision}

The intraday and interday precisions of developed method were determined by estimating the corresponding response three times on the same day and on three different days over a period of week for three different concentrations of amlodipine $(20,25$, and $30 \mu \mathrm{g} / \mathrm{ml})$ respectively. The results are reported in terms of relative standard deviation in Table 4.

\section{RESULTS \& DISCUSSION}

The main objective of the International Conference on Harmonization [11] for validation of an analytical procedure is to demonstrate that it is suitable for its intended purpose, and the parameters that need to be selected are the responsibility of the analyst. Ethanol was 
Indo Global Journal of Pharmaceutical Sciences, 2015; 5(3): 205-209

used as solvent for Amlodipine. Amlodipine in plasma, ethanol and water $(1: 1: 8)$ showed absorption maxima at $343 \mathrm{~nm}$ in UV spectrum. The response for Amlodipine was found to be linear in the concentration range of 5-30 $\mu \mathrm{g} / \mathrm{mL}$. The optical characteristics of the method and regression analysis of the calibration curve are shown in table 3. The recovery of Amlodipine was found to be satisfactory. Excipients used in the specificity study did not interfere with response of the drug at its analytical wavelength. Also, no significant change in response of Amlodipine was observed after 24 hrs. Hence, the method is specific and robust for estimation of Amlodipine.

Table 1: Calibration curve data for amlodipine in rat plasma

\begin{tabular}{|c|c|}
\hline $\begin{array}{c}\text { Concentration } \\
(\boldsymbol{\mu g} / \mathbf{m l})\end{array}$ & Absorbance \\
\hline $5 \mu \mathrm{g}$ & 0.18 \\
\hline $10 \mu \mathrm{g}$ & 0.34 \\
\hline $15 \mu \mathrm{g}$ & 0.5 \\
\hline $20 \mu \mathrm{g}$ & 0.66 \\
\hline $25 \mu \mathrm{g}$ & 0.82 \\
\hline $30 \mu \mathrm{g}$ & 0.99 \\
\hline
\end{tabular}

Table 2: Assay result of amlodipine in tablets

\begin{tabular}{|l|l|l|l|}
\hline $\begin{array}{l}\text { Tablets Label } \\
\text { claim } \\
\text { (mg/tab) }\end{array}$ & $\begin{array}{l}\text { Amount } \\
\text { found } \\
\text { (mg/tab) }\end{array}$ & $\begin{array}{l}\text { Standard } \\
\text { deviation }\end{array}$ & $\begin{array}{l}\text { \% Mean } \\
\text { recovery }\end{array}$ \\
\hline 10 & 9.2 & 2.0412 & 99.77 \\
\hline
\end{tabular}<smiles>CCOC(=O)C1=C(COCCN)NC(C)=C(C(=O)OC)C1c1ccccc1Cl</smiles>

Figure 1: Structure of amlodipine

Table 3: Accuracy of amlodipine in rat plasma

\begin{tabular}{|c|c|c|c|c|c|c|c|c|c|}
\hline S.No & $\begin{array}{l}\text { Amount } \\
\text { present } \\
(\mu \mathrm{g} / \mathrm{ml})\end{array}$ & $\begin{array}{l}\text { Amount } \\
\text { added }\end{array}$ & $\begin{array}{l}\text { Amount } \\
\text { estimated }\end{array}$ & $\begin{array}{l}\text { Amount } \\
\text { recovered }\end{array}$ & $\begin{array}{l}\% \\
\text { Recovery }\end{array}$ & Mean & SD & $\%$ RSD & SEM \\
\hline \multirow[b]{3}{*}{1} & 20 & 2 & 12 & 2 & 100 & \multirow{3}{*}{100.4} & \multirow{3}{*}{2.04} & \multirow{3}{*}{2.03} & \multirow{3}{*}{0.20} \\
\hline & 25 & 2 & 22 & 2.07 & 102.7 & & & & \\
\hline & 30 & 2 & 32 & 1.97 & 98.7 & & & & \\
\hline \multirow[b]{3}{*}{2} & 20 & 4 & 14 & 3.87 & 96.27 & \multirow{3}{*}{97.91} & \multirow{3}{*}{2.48} & \multirow{3}{*}{2.53} & \multirow{3}{*}{0.25} \\
\hline & 25 & 4 & 24 & 4.03 & 100.77 & & & & \\
\hline & 30 & 4 & 34 & 3.86 & 96.7 & & & & \\
\hline \multirow[b]{3}{*}{3} & 20 & 6 & 16 & 6.27 & 104.7 & \multirow{3}{*}{105.17} & \multirow{3}{*}{2.28} & \multirow{3}{*}{2.17} & \multirow{3}{*}{0.22} \\
\hline & 25 & 6 & 26 & 6.19 & 103.167 & & & & \\
\hline & 30 & 6 & 36 & 6.34 & 107.667 & & & & \\
\hline
\end{tabular}

Table 4: Intraday and interday precision of amlodipine in rat plasma

\begin{tabular}{|c|c|c|}
\hline \multirow{4}{*}{ Precision } & Interday & Intraday \\
\cline { 2 - 3 } & Rat Ethanol & Rat Ethanol \\
\cline { 2 - 3 } & $\mathbf{3 0 \mu g}$ & $\mathbf{3 0 \mu g}$ \\
\cline { 2 - 3 } & 0.6013 & 0.6013 \\
\cline { 2 - 3 } & 0.6049 & 0.604 \\
\cline { 2 - 3 } & 0.6013 & 0.6015 \\
\cline { 2 - 3 } & 0.6013 & 0.6015 \\
\hline \multirow{4}{*}{ Mean } & 0.605 & 0.609 \\
\hline RSD & 0.602 & 0.601 \\
\hline
\end{tabular}


Indo Global Journal of Pharmaceutical Sciences, 2015; 5(3): 205-209

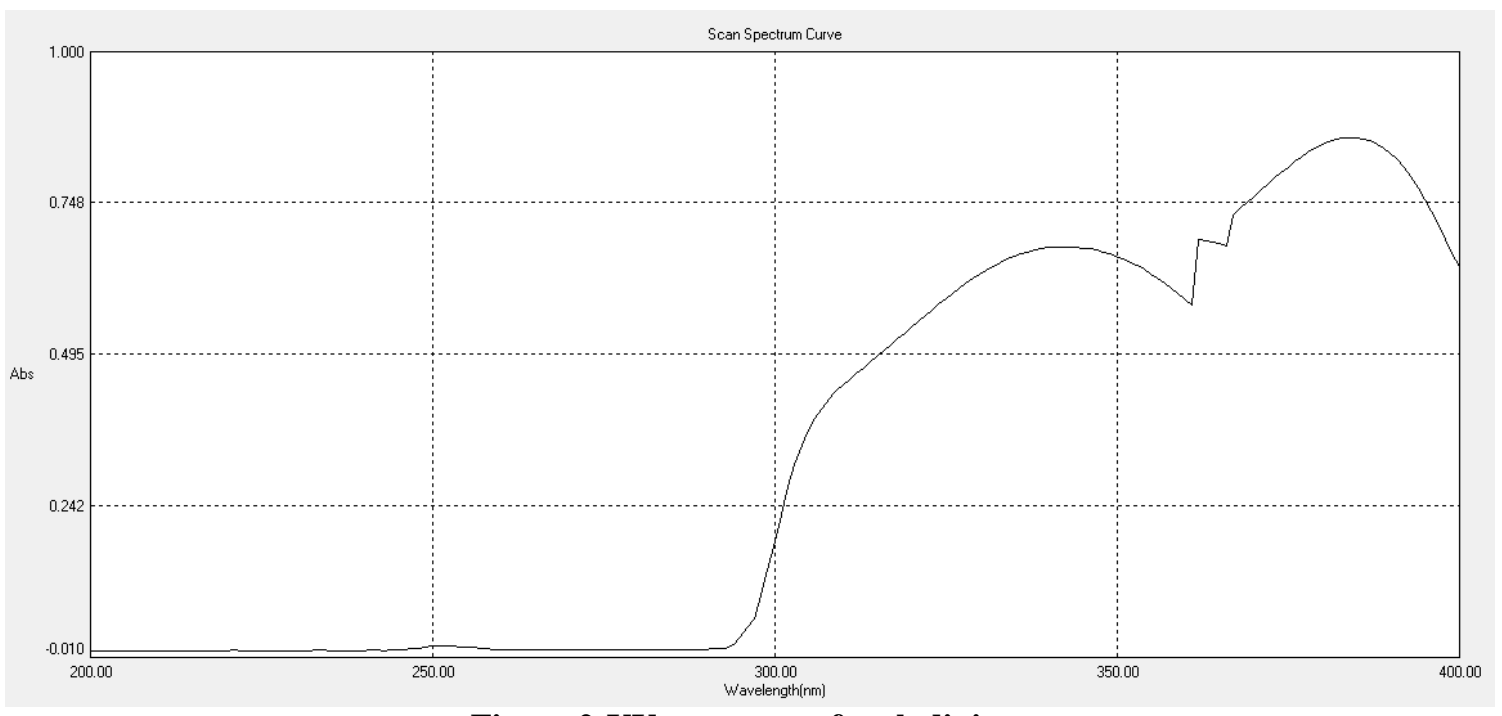

Figure 2:UV spectrum of amlodipine.

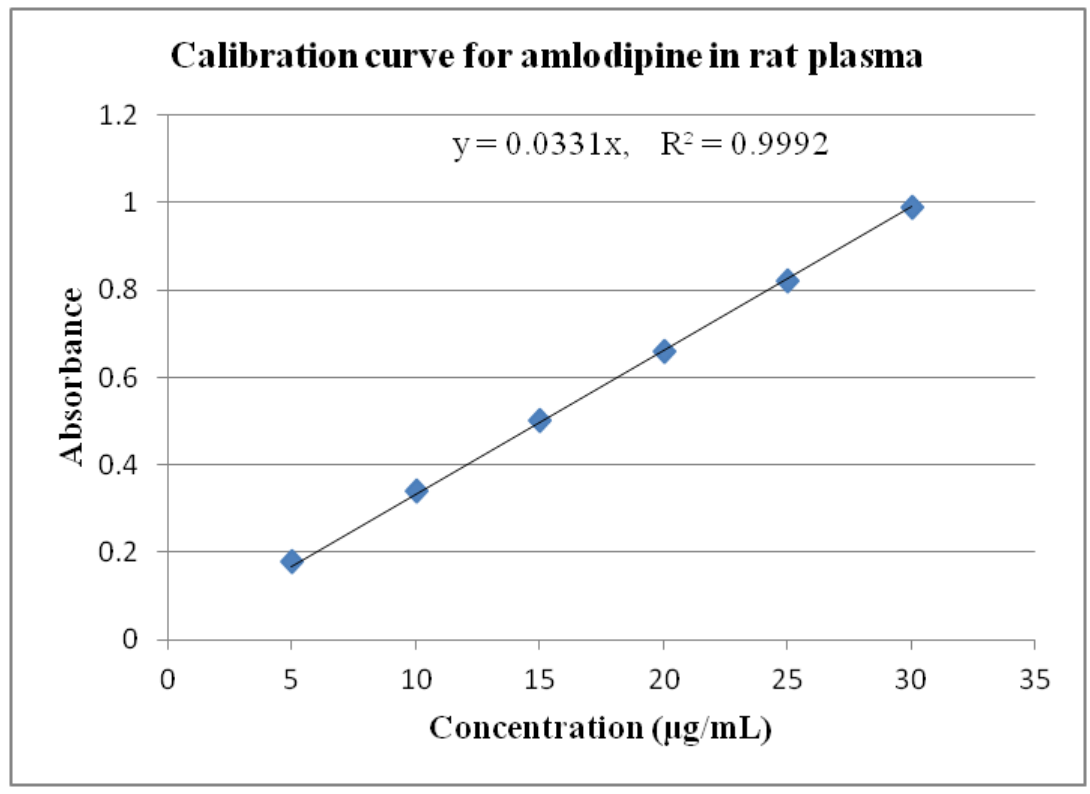

\section{CONCLUSION}

The method was validated and found to be simple, sensitive and precise. Hence, the method can be used successfully for routine analysis of pharmaceutical dosage form of amlodipine.

\section{ACKNOWLEDGMENT}

The authors are thankful to Chebrolu Hanumaiah Institute of Pharmaceutical Sciences, Guntur, for providing the facilities.

Figure 3: Calibration curve of amlodipine at $343 \mathrm{~nm}$.

\section{REFERENCES}

[1] Luksa J, Josíc D, Podobnik B, Furlan B, Kremser M (June 1997). "Semi-preparative chromatographic purification of the enantiomers S-(-)-amlodipine and R-(+)-amlodipine". J. Chromatogr. B Biomed. Sci. Appl. 693 (2): 367-75.

[2] Wang, JG (2009). "A combined role of calcium channel blockers and angiotensin receptor blockers in stroke prevention". Vascular health and risk management 5: 593-605.

[3] Bhandary Ashesh, et al. "Non-compartmental pharmacokinetics modeling of Amlodipine in rats."

[4] Pfizer (February 2006). "Norvasc (amlodipine besylate): official site". New York City,New York: Pfizer Inc. Archived from the original on 2014-02-26. Retrieved 2014-02-26.

[5] Ma, Yuanyuan, et al. "Determination and pharmacokinetic study of amlodipine in human plasma by ultra performance liquid chromatography-electrospray ionization mass 
Indo Global Journal of Pharmaceutical Sciences, 2015; 5(3): 205-209

spectrometry." Journal of pharmaceutical and biomedical analysis 43.4 (2007): 1540-1545.

[6] Rojas, F. Sánchez, and C. Bosch Ojeda. "Recent development in derivative ultraviolet/visible absorption spectrophotometry: 2004-2008: A review."Analyticachimicaacta 635.1 (2009): 2244.

[7] Kasture, A. V., and MadhuriRamteke. "Simultaneous UVspectrophotometric method for the estimation of atenolol and amlodipine besylate in combined dosage form." Indian journal of pharmaceutical sciences 68.3 (2006): 394.

[8] Soni, Balram, et al. "Determination of Lornoxicam in plasma by UV spectroscopy." Pharmacophore (Int. reserch j.) 2.4 (2011): 239-243.
[9] Tatar, Sevgi, and SedefAtmaca. "Determination of amlodipine in human plasma by high-performance liquid chromatography with fluorescence detection." Journal of Chromatography B: Biomedical Sciences and Applications 758.2 (2001): 305-310.

[10] Parikh, N. N., et al. "Development and validation of analytical methods for simultaneous estimation of lornoxicam and eperisone in synthetic mixture." Pharma Science Monitor 5.2 (2014).

[11] International Conference on Harmonization of Technical Requirements for Registration of Pharmaceuticals for Human Use (Nov. 6, 1996) "Validation of Analytical Procedures: Methodology" ICH Steering Committee, Geneva, Switzerland.

Indo Global Journal of Pharmaceutical Sciences( ISSN 22491023 ; CODEN- IGJPAI; NLM ID: 101610675) indexed and abstracted in EMBASE(Elsevier), SCIRUS(Elsevier),CABI, CAB Abstracts, Chemical Abstract Services(CAS), American Chemical Society(ACS), Index Copernicus, EBSCO, DOAJ, Google Scholar and many more. For further details, visit 